\title{
The Effects of Corruption on Employment (A Perception of Rural Educated Youth)
}

\author{
Manzoor Qadar*, Muhammad Ibrar**, Mussawr Shah*** Waqas****, \\ Liaqat Ali*****, Ismeal Afzal****** And Muhammad Israr******* \\ *Ph.D scholar Institute of Social Work, Sociology and Gender Studies, The University of Peshawar, Peshawar, \\ Pakistan. \\ ** M.Phil scholar Department of Rural Sociology, The University of Agriculture Peshawar Pakistan. \\ *** Professor/Chairman Department of Rural Sociology, The University of Agriculture Peshawar Pakistan. \\ **** M.Phil scholar Department of Rural Sociology, The University of Agriculture Peshawar Pakistan. \\ ***** M.Phil scholar Department of Rural Sociology, The University of Agriculture Peshawar Pakistan. \\ ****** Lecturer Department of Management Sciences, Abdul Wali Khan University Mardan Pakistan. \\ ******* Lecturer Department of Sociology, Abdul Wali Khan University Mardan Pakistan.
}

\begin{abstract}
The major objective of this research study was to ascertain the relationship between social inequality, institutional disorder and unemployment was conducted with special reference to seven selected villages of Union Council Shahi-Khel, District Dir Lower, Khyber Pakhtoon-Khwa, Pakistan. A sample size of 359 households were proportionally allocated to each village and then randomly selected. Both uni-variate and bi-variate analyses were carried out to determine outcomes. The association between dependent variable (unemployment) and independent variable (social stratification) was tested by using Chi-Square Test. The relationship between family institution and unemployment reveal that unemployment is having significant association with people of strong emotional background $(P=0.000)$, facilitated individual $(P=0.012)$, family motivation for an individual $(P=0.000)$, family preferences $(P=0.002)$, family expectations $(P=0.000)$, rich and powerful families $(P=0.000)$, officer's son is officer and labourer's son as labourer $(P=0.000)$, emotional support from the family $(P=0.000)$, negative attitude with family $(P=0.002)$ and unemployment. It is concluded that the perception of youth about family as it give sound foundation to personality of its members ensuring their success in every walk of life, especially in getting employment. Family believed to be ever pushing its members for getting employment and in majority of cases uses it influence in society to secure employment of its members. However, preferences for specific jobs, high expectations from the educated youth and low economic and emotional support from families pose obstacle to employment of youth.
\end{abstract}

Key Words: Unemployment, Family Institution.

\section{Introduction}

Persons are classified as unemployed if they do not have a job, have actively looked for work in the prior four weeks and are currently available for work. Persons who were not working and were waiting to be recalled to a job from which they had been temporarily laid off are also included as unemployed. Unemployment is the lack of livelihood-producing work Unemployment is the lack of livelihood-producing work. Since the rise of capitalism, unemployment has increased and the population of the world is in fastest growing process. It has nearly four folded since 1950 and is expected to rise more than double over the next fifty years but jobs have not grown as fast as the global workforce (ILO, 2001). The people belong to the upper class or well educated families; get the job without any nervous strain as compared to the lower class families. Some families provide negatively to employment of the youth and they prefer job for the family member that belongs to the family status and according to the education of the youth. The youth itself avoid applying to those positions which are not according to their qualification (Lovell, 2010). However, family expectation and education for an appropriate job in the rural areas become reasons for the unemployment of the rural youth (Ayinde, 2008).

Michael et al., (1984) remarked that youth along with their education do part time jobs for their basic earnings. Mostly the youth less than sixteen years search for jobs because of the low income of the family. These youth support their family and take responsibilities on their shoulders to keep them up in the society. The youth often fail to keep their education and prestige in the society due to their early employment decision which is their basic need to live. The youth want to get education for a better life but the early responsibilities make them restricted to earn for their family. They sacrifice their leisure time in earning money and finally lost the way to get education. It is not the fault of youth but the situation make youth for a bright dream of the future in 
their eyes. The youth when do not get education cannot meet the modern day demand and often lay off as unemployed.

Yeatts (1995) determined that the majority of youth in the colleges spend their earnings and family allowances on extra activities. Young generation have various needs for looking employment. They hunch and the primary reasons for work are to detect personal usance over and above what father or mother are inclined toward youth through sum granted. arnings from employment and ultimate freedom from their parents set a stage for independence and finally youth loss their way of education. Loosing way of education, love for freedom and thinking of luxurious life makes rural youth laid off in future with a dark face.

Dickinson (1999) explored the fact that food, clothing and shelter generally provide by the parents to their children. The parents earn money for their children's good socialization and usually facilitate them with everything they wish. The parents are very sensitive about their future. They are in favour of the children's well education and try to provide a well stabilize step towards a good job. The parents even do not think about others but for the bright future of their children. The privileged family member often employed but under privileged talented person will be without job due to the fact that poor are only confined to their livelihood but on the other rich family make their child on a high position.

Rees and Gray (1982) described that the family of a youth is important in assisting youth in finding their jobs, whilst they dealt school registration as originating externally. The educated family helps the youth to be educated like their parents. The family from the lower class will not support the youth as much the upper class. The family from the upper class often get the jobs but the lower class is free from all that assessment and support. That is why we can see more psycho cases in the lower class than the upper class.

Goldfarb and Yezer (1983) purported a framework of labour provision while on the contrary the primary social group is regarded as grading time confinements on adolescents that alter with years, gender and if the adolescents dwells with the primary social group and every adolescent make as big their possess usefulness. Adolescents accedes labour mart in dissimilar time and unlike gender and get their money for a better future. The family supports adolescents and teens but sometimes face restraints from the family due to various social, economic and cultural problems. Like in Pashtun society women get education but mostly lay off due to family constraints.

O'Regan and Quigley (1998) conducted an inquiry that approach to an employment mainly based on the time of travel to an average job by the average worker. The census is must to know in an area that how much are unemployed, how much is racial differences and how much poor people are living there. The researcher probed characteristics of the individual level and of the household in the neighbourhood composition to a significant level and their accessibly to employment. Including these factors the researcher found that individual level and household characteristics have minimised to a large magnitude and their approach to job was in a positive sense but however due to biasness existence, there were still unemployment problems.

\section{Materials And Methods}

The study universe comprised of union council Shahi-Khel Talash, Tehsil Timergara, District Dir Lower Khyber Pakhtun-Khwa, Pakistan. More specifically the universe comprised of seven villages, namely Ziarat, Muslimabad, Kulalabad, Khatkalay, Kalpani, Faqirabad and Madinaabad. The study universe helped in timely and economic achievement of study objectives. According to district census report (1998), total population of seven villages of the study universe comprised of 4880 households. As the research involved multiple variables, the suitable sample size determination was provided by Sekaran (2003), according to which a sample size of 359 was selected through proportionate stratified random sampling technique. Village wise population and sample size is given in Table 1.

Table 1: Proportionate Allocation of Sample Size to Various Villages in Study Universe

\begin{tabular}{|l|l|l|l|} 
Serial No. & Name of Village & Total Household & Sample Size \\
\hline 1 & Ziarat & 1256 & 92 \\
\hline 2 & Muslimabad & 723 & 53 \\
\hline 3 & Kulalabad & 668 & 49 \\
\hline 4 & Khatkalay & 615 & 45 \\
\hline 5 & Kalpani & 557 & 42 \\
\hline 6 & Faqeerabad & 548 & 41 \\
7 & Madinaabad & 514 & 37 \\
Total & Seven villages & $\mathbf{4 8 8 0}$ & \\
\hline
\end{tabular}

*Source:Union Council Shahi-Khel office record

A conceptual framework was devised and questions were asked accordingly from the respondents devised through questionnaire. The dependent variable (unemployment) was indexed to measure the level of association with independent variable (corruption). This association at bi-variate level was tested through Chisquare test outlined by Tai (1978) shown below;

Following statistical procedure were adopted to calculate the value of chi-square statistics. 
with (r-1) (c-1) degrees of freedom

$\mathrm{X}^{2}=$ Chi-square for categorical variables

Oij $=$ observe frequency in $i^{\text {th }}$ row and $j^{\text {th }}$ column

$=$ expected frequency corresponding to $\mathrm{i}^{\text {th }}$ row and $\mathrm{j}^{\text {th }}$ column

The degree of freedom was calculated as:

$\mathrm{r}=$ number of rows

$\mathrm{c}=$ number of columns.

\section{Role of Family Institution Employment of Youth}

\section{Results and Discussion}

Family is the basic social institution, especially in the rural context and has vital role in the integration and moral upbringing of its members. Perception of respondents about role of family in unemployment is given in Table 2. The result show that a high proportion i.e. 49.9 percent respondents perceived that people with strong emotions, sentiments and enthusiasm are from good families and often get jobs, 63.8 percent agreed that well socialize individual in the family will get job easily, 57.1 percent were of the view that a computer, internet etc. facilitated individual in a family will get job easily, 79.4 percent thought that family motivate the individual to do and search the job for supporting family and himself, 54.6 percent were of the view that preferences for specific jobs, idealised through family which causes unemployment among the rural youth and 58.5 percent were perceived that family expectations from a well-qualified individual not to do job with a low/less pay or with low grade/scale causes unemployment. These findings are supported by Dickinson (1999), who explored that parents provide the strong emotional background, facilitations, motivations and then expect to do what they want to become in the practical field. The family preferences for specific jobs make youth to search a high profile job, which often results in unemployment for the youth. Similarly 69.1 percent respondents perceived that rich and powerful family helps to provide opportunities to its members through nepotism and bribery for securing job, 59.6 percent thought that an officer's son is an officer and a labourer's son as labourer. These findings supported by Rees and Gray (1982) who described that the family of a youth is important in assisting youth in finding their jobs. The privileged family member often employed in a high position but under privileged talented person is often without job. However, 48.5 percent respondents were of the view that no economic and emotional support from the family is a reason for the unemployment of the rural youth and 50.7 percent were perceived that deviant behaviour of the individual in the family is a cause for the unemployment. These findings are supported by Goldfarb and Yezer (1983), who found that youth enters the labour market in the early ages, makes their future dark because of the lack of education and lust for money. The result help to understand the perception of youth about family as it give sound foundation to personality of its members ensuring their success in every walk of life, especially in getting employment. Family believed to be ever pushing its members for getting employment and in majority of cases uses it influence in society to secure employment of its members. However, preferences for specific jobs, high expectations from the educated youth and low economic and emotional support from families pose obstacle to employment of youth.

Table 2: Frequencies and Percentage Distribution of Respondents According to Their Perception regarding Role of Family Institution in Employment ( $N=359)$

\begin{tabular}{|c|c|c|c|}
\hline Statement & Yes & No & Don't know \\
\hline $\begin{array}{l}\text { People with strong emotions, sentiments and enthusiasm are from } \\
\text { good families and often get jobs }\end{array}$ & 172(49.9) & 149(41.5) & $38(10.6)$ \\
\hline Well socialize individual in the family will get job easily & $229(63.8)$ & $101(28.1)$ & $29(8.1)$ \\
\hline $\begin{array}{l}\text { A facilitated (computer, internet etc.) individual in a family get job } \\
\text { easily }\end{array}$ & $205(57.1)$ & 115(32.0) & $39(10.9)$ \\
\hline $\begin{array}{l}\text { Family motivate the individual to do and search the job for supporting } \\
\text { family and himself }\end{array}$ & 285(79.4) & 48(13.4) & $39(10.9)$ \\
\hline $\begin{array}{l}\text { Preferences for specific jobs, socialised through family causes } \\
\text { unemployment }\end{array}$ & $196(54.6)$ & $120(33.4)$ & $43(12.0)$ \\
\hline $\begin{array}{l}\text { Family expectations from a well-qualified individual not to do job } \\
\text { with a low/less pay or with low grade/scale causes unemployment }\end{array}$ & $210(58.5)$ & $119(33.1)$ & $30(8.4)$ \\
\hline $\begin{array}{l}\text { Rich and powerful family helps to provide opportunities of nepotism } \\
\text { and bribery for securing job }\end{array}$ & $248(69.1)$ & $76(21.2)$ & $35(9.7)$ \\
\hline An officer's son is an officer and a labourer's son as labourer & 214(59.6) & $118(32.9)$ & $27(7.5)$ \\
\hline $\begin{array}{l}\text { No economic and emotional support from the family is a reason for } \\
\text { the unemployment of the youth }\end{array}$ & $174(48.5)$ & $150(41.8)$ & $35(9.7)$ \\
\hline $\begin{array}{l}\text { Deviant behaviour of individual in family causes unemployment for } \\
\text { the youth }\end{array}$ & $182(50.7)$ & $127(35.4)$ & $50(13.9)$ \\
\hline
\end{tabular}

*Data \& table show frequencies \& parenthesis show the percentages. 


\section{Association between Perceived Role of Family Institution and Unemployment}

The family is an intimate domestic group made up of people related to one another by bonds of blood, sexual mating or legal ties. It has been a very resilient and social unit that has survived and adapted through time. Families and work have been related to one another. An individual earns for his family and support it by all means. If s/he is unemployed and cannot support the family then it can be difficult to live independently. A well socialised individual with strong family support is more apt to success. To reach to reliable association between role of family institution in ensuring employed and perception of unemployment the variables were limited to few statements as given in Table 3 . The bivariate results unveil that a highly significant $(\mathrm{P}=0.000)$ association between people with strong emotional background and unemployment was found and it explores that people with strong emotional background, sentiments and enthusiasm are from good families and often get jobs. Similarly, a significant $(\mathrm{P}=0.012)$ association was found between facilitated individual and unemployment. The result describes that a facilitated individual inside a family will not be unemployed because the facilities provided to him can help him to encash every desirous employment opportunity. Likely, a highly significant $(\mathrm{P}=0.000)$ association was found between motivation from family for an individual and unemployment. It reveals that family motivate the individual to do and search the job for supporting family and himself. Family motivation is very important, in motivation and encouragement for securing job and a place of consolation in case of failure. Furthermore, A highly significant $(\mathrm{P}=0.002)$ association was found between family preferences for specific jobs and unemployment. Preferences for specific jobs internalised through family which causes unemployment as they have focused and specific aim with no alternates. In addition, a highly significant $(\mathrm{P}=0.000)$ association was found between family expectations and unemployment. It explores those family expectations from a well-qualified individual not to do job with a low/less pay or with low grade/scale, failing to which is causing social stigma and source of bad name to family. These findings are supported by Dickinson (1999), who explored that parents provide the strong emotional background, facilitations, motivations and then expect to do what they want to become in the practical field. The family preferences for specific jobs make youth to search a high profile job, which often results in unemployment for the youth. Moreover, a highly significant $(\mathrm{P}=0.000)$ association was found between rich and powerful families and unemployment which explores that rich and powerful family helps to their members in ensuring employment opportunities through nepotism and bribery for securing job. Likewise, A highly significant $(\mathrm{P}=0.000)$ association was found between hereditary right of employment and unemployment. The data describes that an officer will provide every facility and legal and illegal ways to see him as an officer but on the other hand a labour will only look for his earning for livelihood as result rich remain on higher status, confining poor to odd jobs. These findings are supported by Rees and Gray (1982) and Dickinson (1999), whom described that the family of a youth is important in assisting youth in finding their jobs. The privileged family member often employed on higher positions but under privileged talented person would be without job. Equally, a highly significant $(\mathrm{P}=0.000)$ association was found between no economic and emotional support from family and unemployment which explores that no economic and emotional support from the family is a reason for the unemployment of the youth. Furthermore, a significant $(\mathrm{P}=0.002)$ association was found between negative attitude with family and unemployment. These findings are supported by Goldfarb and Yezer (1983), who found that youth enters the labour market in the early ages, makes their future dark because of the lack of education, lust for money and poor guidance, especially from their families. In contrast, a non-significant $(\mathrm{P}=0.107)$ association between socialized individual and unemployment was found. The result is against the findings of Dickinson (1999), who explored that family idealised individual for a specific job through which they can achieve their positions. The result explores that general perception about role of family in securing employment. It is believed that the family socialises individual to idealise role models and aim high status jobs as their aim. A strong motivation backed by socialisation social conciliation and high economic supply ensures securing high profile job. Conversely, poor family background is lacking in motivation and financial support so any opportunity availed is welcomed that's why the poor are stacked in the wishes circle.

Table 3: ( $N=359)$ Association between Family Institution and Unemployment

\begin{tabular}{|l|l|l|l|l|l|l|}
\hline \multirow{2}{*}{ Family institution } & Perception & \multicolumn{3}{|c|}{ Unemployment } & \multirow{2}{*}{$\begin{array}{l}\text { Total } \\
\text { (P-Value) }\end{array}$} \\
\cline { 3 - 6 } & & Yes & No & Don't know & \\
\hline $\begin{array}{l}\text { People with strong } \\
\text { emotions are from good } \\
\text { families \& often get jobs }\end{array}$ & Yes & No & $158(44.0)$ & $14(3.9)$ & $0(0.00)$ & $172(47.9)$ \\
\cline { 2 - 6 } & Don't know & $22(6.1)$ & $119(33.1)$ & $25(7.0)$ & $5(1.4)$ & $149(41.5)$ \\
$(0.000)$ \\
\hline $\begin{array}{l}\text { Socialized individual in } \\
\text { family get job easily }\end{array}$ & Yes & $199(55.4)$ & $28(7.8)$ & $2(0.6)$ & $229(63.8)$ \\
\cline { 2 - 6 } & No & $77(21.4)$ & $21(5.8)$ & $3(0.8)$ & $0(0.00)$ & $101(28.1)$ \\
\cline { 2 - 6 } & Don't know & $23(6.4)$ & $6(1.7)$ & $0(0.00)$ & $29(8.1)$ \\
\hline
\end{tabular}


The Effects of Corruption on Employment (A Perception of Rural Educated Youth)

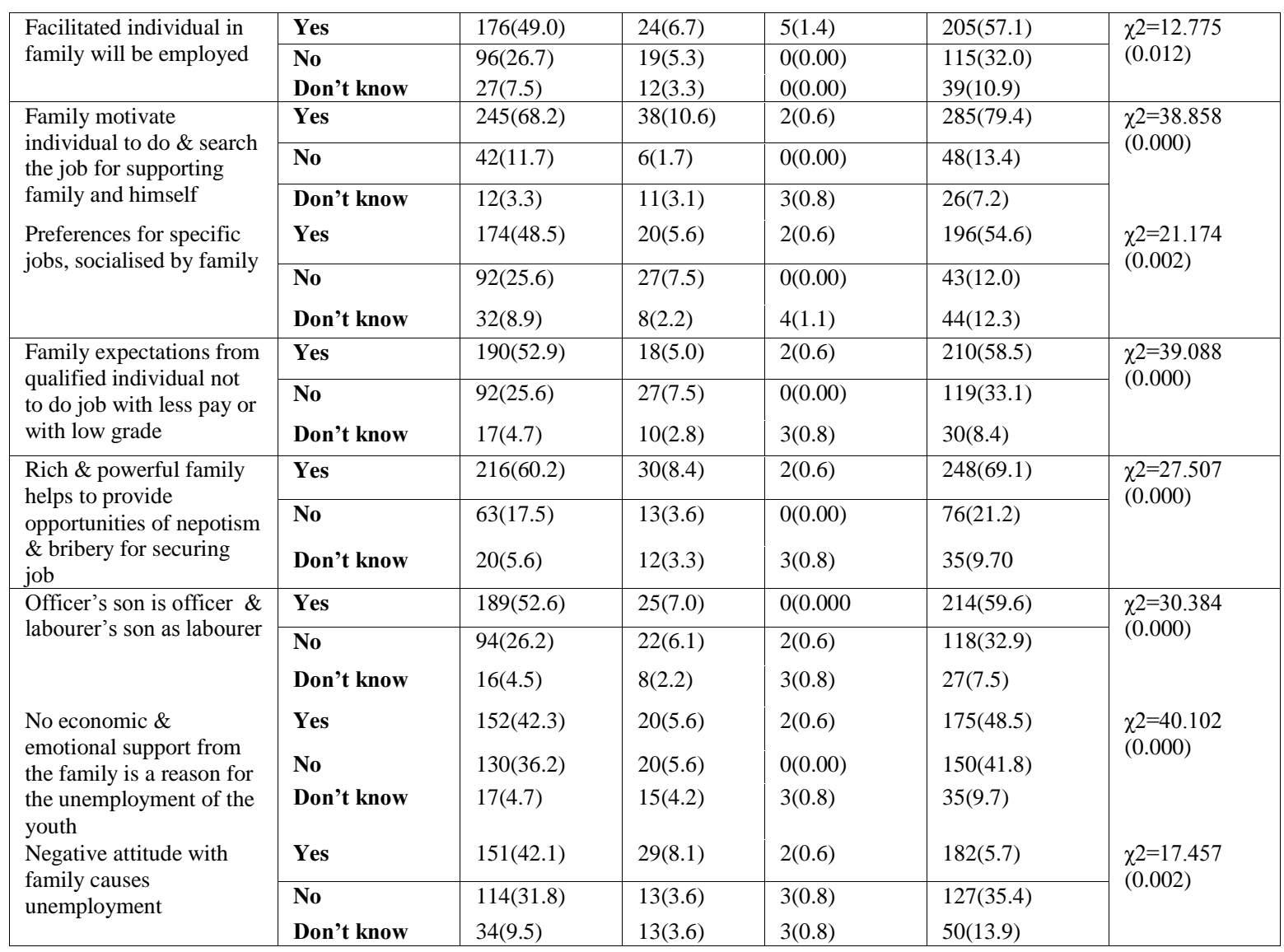

*Number in table represent frequencies and number in parenthesis represent percentage proportion of respondents and in the last columns number in the parenthesis represent $\mathrm{p}$-value.

\section{Conclusion}

Employment is a parameter of social status. The persons of high family prestige and having employed family members are well ahead of rest of their competitors for getting employment, especially is securing high positions. The perception of youth about family as it give sound foundation to personality of its members ensuring their success in every walk of life, especially in getting employment. Family believed to be ever pushing its members for getting employment and in majority of cases uses it influence in society to secure employment of its members. However, preferences for specific jobs, high expectations from the educated youth and low economic and emotional support from families pose obstacle to employment of youth.

\section{References}

[1]. Ayinde, O. E. 2008. Empirical Analysis of Agricultural Growth and Unemployment in Nigeria. African Journal of Agricultural Research. 3(7):465-468.

[2]. Dickinson, A. 1999. The Role of the Family in Determining Youth Employment. http://www.ipr.northwestern.edu/jcpr/workingpapers/wpfiles/pabilonia_WP_ori.pdf (verified on April 7, 2012).

[3]. Goldfarb, R. and Anthony, Y. 1983. A Model of Teenage Labour Supply. Journal of Economics and Business. 35(2):245-255.

[4]. International Labour Organisation. 2001. Youth and Work: Global Trends. Geneva, p.4 http://www.yesweb.org/docs/rdbook.pdf (Verified on April 7, 2012)

[5]. Lovell, P., et al. 2010. Families of the Recession: Unemployed Parents \& Their Children. http://www.brookings.edu/media/Files/rc/papers_families_recession_isaacs_families_recession_isaacs.pdf (verified on April 7, 2012).

[6]. Michael, R. T., et al. 1984. Youth Employment: Does Life Begin at 16. Journal of Labour Economics. 4(1):464-476.

[7]. O'Regan, K. M. 1998. Spatial Effects upon Employment Outcomes. The Case of New Jersey Teenagers. http://papers.ssrn.com (verified on April 7, 2012).

[8]. Rees, A., et al. 1982. Family Effects in Youth Employment in the Youth Labour Market Problem: Its Nature, Causes, and Consequences. 4th Ed., University of Chicago Press, Chicago. 453-464p.

[9]. Yeatts, J. 1995. The Role of the Family in Determining Youth Employment. http://www.ipr.northwestern.edu/jcpr/workingpapers/wpfiles/pabilonia_WP_ori.pdf (verified on April 7, 2012). 